First Peoples Child \& Family Review

A Journal on Innovation and Best Practices in Aboriginal Child Welfare Administration, Research, Policy \& Practice

\title{
Editorial : To Reach Out in Friendship?
}

\section{Terry Cross and Cindy Blackstock}

Volume 2, Number 1, 2005

URI: https://id.erudit.org/iderudit/1069534ar

DOI: https://doi.org/10.7202/1069534ar

See table of contents

Publisher(s)

First Nations Child and Family Caring Society of Canada

ISSN

1708-489X (print)

2293-6610 (digital)

Explore this journal

Cite this document

Cross, T. \& Blackstock, C. (2005). Editorial : To Reach Out in Friendship? First

Peoples Child \& Family Review, 2(1), 5-8. https://doi.org/10.7202/1069534ar viewed online.

https://apropos.erudit.org/en/users/policy-on-use/ 

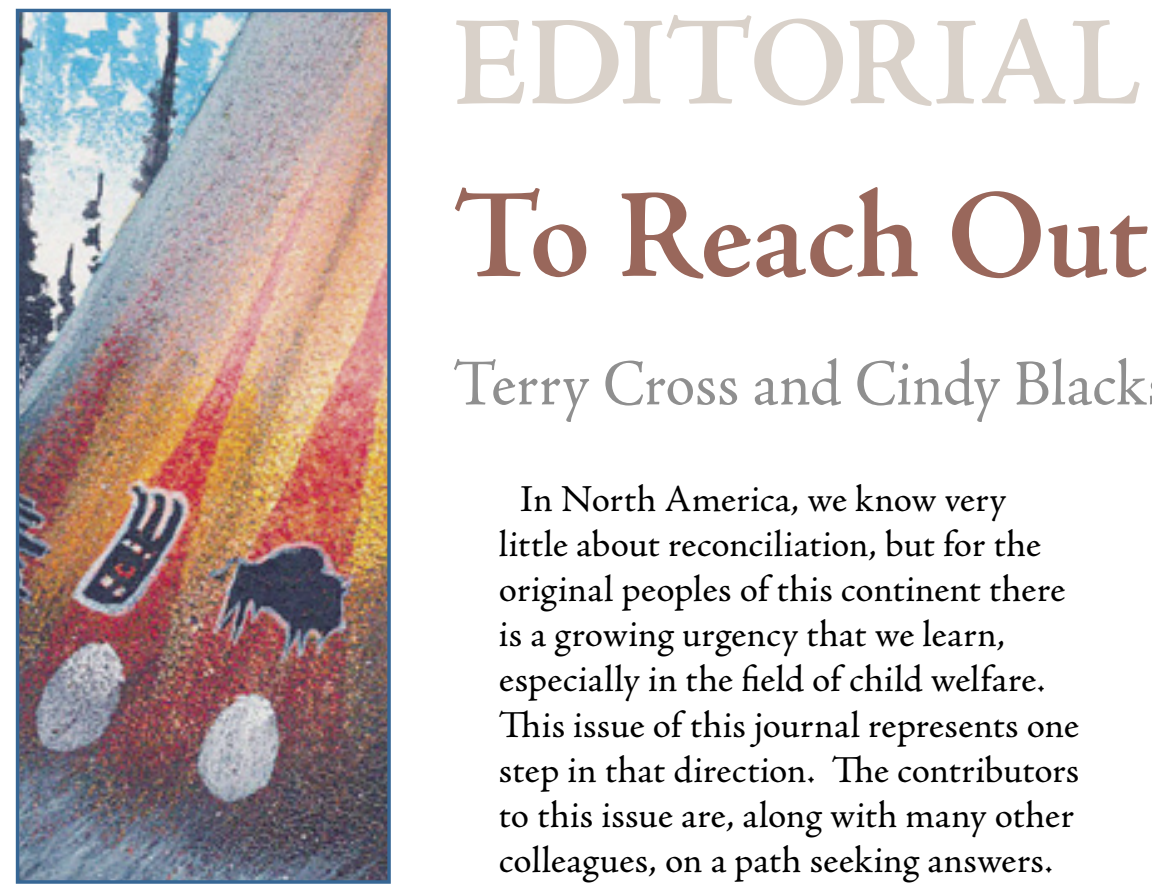

\section{To Reach Out in Friendship?}

\section{Terry Cross and Cindy Blackstock}

In North America, we know very little about reconciliation, but for the original peoples of this continent there is a growing urgency that we learn, especially in the field of child welfare. This issue of this journal represents one step in that direction. The contributors to this issue are, along with many other colleagues, on a path seeking answers. For without a path, there is no hope, and without hope there is no resolution.

Reconciliation takes two willing partners, the injured and the perpetrator. Indigenous peoples of North America, over the past centuries, have experienced oppression, loss, and exclusion. Yet, Indigenous and non-Indigenous peoples understand that the way forward for our children depends on our ability to hear the lessons of the past, learn from them, and carve out in a vigilant way a new relationship together based on respectful co-existence.

One may legitimately wonder if this social conflict is reconcilable. We know that the challenge ahead is significant and that not everyone in our profession is ready for this conversation. Both sides share the desire to make things better. However, the barriers are often the most likely allies for change. It sometimes seems that government is simply a structure to perpetuate injustice. Mainstream helping professionals, policy makers, researchers, and child welfare leaders are made up of people of good intent who, in most cases, care about human rights and justice. Why, then, do they usually conduct their affairs as if we do not exist? Who do we turn to if the good guys ignore us?

In this context, there is risk in even coming to the table. If we are recognized by each other, we can become one through dialogue. If one ignores the other, we are condemned to remain oppressor and oppressed, colonizer and colonized. Christodoulidis in his article "Truth and Reconciliation as Risks" (2000) cites the following quote from Simone Weil (1989):

\section{"You do not interest me." No man can say these words without committing a cruelty and offending against justice.}

The phrase manifests in many forms, such as when Native peoples are ignored in research findings and lumped among the amorphous category "other" or reported as "insignificant." Most often the essence of this phrase appears as acts of omission. It is why policy does not change even when report after report affirms that change is necessary. It is why practice does not change even when helpers are of good will, open mind, and rational thought. It is at least part of the reason that the same government that enacts policy to preserve the family can be the agent of destruction of indigenous families through perpetuation of boarding schools.

The reasons that many interventions in Aboriginal child welfare are unhelpful or destructive stem from two closely related larger societal problems: 1 ) systemic colonialism, a situation that allows the more powerful to take what they want from the less powerful - in this case, Aboriginal peoples; and 2) racism, the treating of Indigenous peoples differently just because of their racial heritage.

If we really care about children and families, we must care about all of them regardless of race or political status. If Indigenous children and societies are to survive, child welfare advocates both Native and mainstream 
know that standing still is not an option. It is up to us to demonstrate leadership on this matter. In both Canada and the United States, too many Indigenous children are living their lives in institutional care, in foster homes, and in corrections facilities. Too many Indigenous parents and community members do not feel supported in their caregiving roles. Our child welfare institutions, although well intended, continue to make mistakes because we have not yet learned to form relationships that result in support that is best for Indigenous children and families.

To redress these problems, a necessary beginning point is to build relationships by engaging in dialogue that will initiate a process of reconciliation between the mainstream child welfare field and the indigenous peoples of the United States and Canada. This dialogue must be founded on principles of respect, understanding, inclusion, and truth. It involves a confirmation of, and learning from, our historical experiences and moving toward a new sustainable relationship that supports children that thrive. This new relationship will foster recognition and support for the right and ability of Indigenous peoples to make the best decisions for Indigenous children. The ultimate goal of this process in both the United States and Canada - for both Aboriginal and non-Aboriginal peoples - is unity in child welfare in support of the well being of children.

As a first step, five national organizations are hosting a North American forum in the fall of 2005 on reconciliation in child welfare. Indigenous and non-Indigenous leaders from communities, professions, and governments - who are committed to changing the way we think and act as social workers to benefit Indigenous children and their families - will convene in the spirit of reconciliation.

Yet the responsibility of the reconciled goes beyond the interpersonal dialogue and a one-time meeting. As reconciliation builds bridges between parties, each party then assumes a responsibility to build bridges within its own constituency for the purpose of furthering the reconciliation agenda. The dialogue provides an alliance(C) Terry Cross and Cindy Blackstock building framework, allowing us to find the common denominators that tell us where to start. Meeting gives us a space for recruiting allies and building the relationships that are the foundation of success. Success will demand that we look beyond making a place for legitimate dialogue to creating a place where we can find common identity as helpers. Finding the space to work together will require the best in each of us, because within that space the demands are great, and once committed, we share dual accountability for our success.

The goal of the initial meeting is to build relationships and engage in dialogue that will initiate a process of truth and reconciliation between the mainstream child welfare field and the indigenous peoples of the United States and Canada. This will necessarily mean acknowledging and affirming the sovereign and moral authority of indigenous peoples' governments to make decisions regarding their children. This event puts in focus current relationships between Indigenous peoples and the child welfare system, calling for a confirmation of, and learning from, our historical experiences and moving toward a new sustainable relationship that supports successful children, and founded on principles of respect, understanding, inclusion, and truth. Together we will strive for excellence in child welfare by:

+ Recognizing, affirming, and supporting the right of Indigenous adults and communities to care for their children and youth;

+ Exploring what reconciliation means for those who have been oppressed in a child welfare context and for those organizations that have, intentionally or unintentionally, been involved in that oppression;

+ Supporting the optimal well-being of Indigenous children, youth, and families as determined and defined by Indigenous peoples;

+ Seeking broad understanding of the ongoing impact of colonialism on child welfare systems; 
+ Understanding the ongoing impacts of colonialism on Indigenous and nonIndigenous peoples and communities and take direct and respectful action to mitigate those impacts.

- Allowing those who have experienced the harm the permission to define that harm and have their reality validated;

- Experiencing reconciliation and healing through high-level engagement in dialogue, experiential activities, and ownership of the issues; and,

+ Engaging in an ongoing and courageous conversation that supports our mutual responsibility to keep watch in order to avoid the mistakes of the past and ensure that our current relationship supports our shared vision.

Our challenge is to build a core leadership movement dedicated to lasting shifts in thought, policies, and practices that support the well-being of indigenous children, families, communities, and culture. The articles presented in this journal are meant to inform others of the process, highlight promising advances, and recruit new allies to the cause. We hope that you are moved as well, by the words of the authors who have so courageously taken the first steps on the journey.

If we are to successfully reach out, we as Indigenous people must call on all the strength passed down to us and begin doing what needs to be done - whether we are seen or not. More than anything else - our vision is that in this process more and more Indigenous peoples light their own candles of hope and believe that the strength within them is enough to do what needs to be done to safely care for our children. The work will be easier, quicker, and more effective if we have allies. It is our mission to reach out in friendship but to not wait anymore.

Christodoulidis, E.A. (2000) "Truth and Reconciliation as Risks." Social and Legal Studies. Vol. 9:(2) 179-204.

\section{Terry L. Cross, MSW, ACSW, LCSW}

Terry Cross is an enrolled member of the Seneca nation of Indians and is the developer and founder of the National Indian Child Welfare Association

(NICWA). He is the author of Heritage and Helping, an eleven manual curriculum for tribal child welfare staff including a volume on working with substance abusing families. $\mathrm{Mr}$. Cross is also author of the positive Indian parenting curricula, as well as crosscultural skills in Indian child welfare. $\mathrm{He}$ also co-authored "toward a culturally competent system of care" published by Georgetown university, child development center. His life and work in both Indian and non-Indian settings and his academic background give him unique skills to serve the project. He has 30 years of experience in child welfare, including 10 years working directly with children and families. Mr. Cross served on the faculty of Portland State University School of Social Work for 15 years. He has served on the board of the national committee to prevent child abuse and has been an advisor to the American professional society on the abuse of children. Mr. Cross has directed the Indian child welfare association since it's founding in 1983 and has traveled to make presentations internationally in relation to child welfare work. Terry is experienced in evaluation design, and policy related research and has organized culturally specific technical assistance programs for over 16 years.

\section{Cindy Blackstock, B.A., M.M.}

A member of the Gitksan Nation, Cindy has worked in the field of child and family services for over twenty years on the front line, in professional development and research. In her current capacity, Cindy is honoured to be the Executive Director of the First Nations Child and Family Caring Society of Canada (www. fncfcs.com) This national organization seeks promotes the works and knowledge of First Nations child and family service agencies and regional organizations in Canada by providing research, professional development and networking services. 
Cindy was honoured to participate in numerous provincial and national research projects. She has published numerous research papers, articles and curriculum related to Aboriginal child welfare in Canada. Current professional interests include being a member of the NGO Working Group of the United Nations Convention on the Rights of the Child, member of the United Nations Indigenous Sub Group for the CRC, Board of Directors for Boys and Girls Clubs of Canada and the Canadian Coalition for the Rights of the Child. 